\title{
Tedi Sudrajat
}

Fakultas Hukum Universitas Jenderal Soedirman Purwokerto.

Jl. Prof. Dr. H.R. Boenyamin, No.708, Grendeng, Grendeng, Purwokerto Utara, Kabupaten

Banyumas, Jawa Tengah

e-mail: tedi.unsoedagmail.com

Agus Mulya Karsona

Fakultas Hukum Universitas Padjadjaran. Jalan Dipati Ukur No. 35 Bandung 40132.

\section{Menyoal Makna Netralitas Pegawai Negeri Sipil dalam Undang-Undang Nomor 5 Tahun 2014 Tentang Aparatur Sipil Negara}

\begin{abstract}
Problems of neutrality of civil servants will always occur when the meaning of neutrality does not have clear standards and criteria. In order to evaluate governance, the meaning of neutrality should be broader and more functional towards the legal relationship in the context of public official relation in the field of civil servants law. Substantially, the focus of Law Number 5 Year 2014 concerning Civil State Apparatus just make civil servants as an object of neutrality, regardless of the dynamic activity of practical politic intervention. It should be underlined that the role of civil servants in government always correlate with many interested parties. If neutrality is not matched by standard criteria and restrictions, it is very possible neutrality principle only be a slogan with minimum implementation.

Keywords : Meaning, Neutrality, Civil Servants
\end{abstract}

\footnotetext{
ABSTRAK

Problematika netralitas Pegawai Negeri Sipil (PNS) akan selalu terjadi ketika makna netralitas belum memiliki standar dan kriteria yang jelas. Mengevaluasi perkembangan di lingkungan pemerintahan, makna netralitas seharusnya dapat lebih luas dan lebih fungsional ke arah hubungan hukum dalam konteks pelaksanaan hubungan dinas publik dalam bidang kepegawaian. Secara substansial, fokus UU Nomor 5 Tahun 2014 tentang Aparatur Sipil Negara hanya menjadikan PNS
}

sebagai obyek netralitas, terlepas dari dinamisasi kegiatan politik praktis yang sarat intervensi. Perlu digarisbawahi bahwa peran PNS dalam pemerintahan selalu berkorelasi dengan banyak pihak yang berkepentingan. Jika netralitas tidak diimbangi oleh kriteria dan standar pembatasan, maka sangat dimungkinkan asas netralitas hanya menjadi slogan yang minim implementasi.

Kata kunci : Makna, Netralitas, Pegawai Negeri Sipil

\section{PENDAHULUAN}

Tidak dapat dipungkiri bahwa persoalan netralitas Pegawai Negeri Sipil (PNS) seperti tidak pernah terselesaikan. Pemerintah telah membuat ragam pengaturan untuk membatasi hubungan PNS dengan kegiatan politik praktis guna memperkuat eksistensi dari netralitas. Namun apa ayal dikata, setiap berlangsungnya kegiatan Pemilihan Umum selalu diwarnai oleh maraknya pemberitaan tentang pelanggaran netralitas oleh oknum PNS. Hal ini berarti bahwa akar persoalan netralitas PNS belum 
terjawab dan dapat diasumsikan bahwa pemerintah masih kesulitan menemukan formulasi yang tepat untuk menjawab problematika netralitas.

Berdasarkan fakta sejarah, kerentanan PNS dalam politik praktis dipengaruhi oleh keterlibatan PNS dalam menyukseskan salah satu pasangan calon kepala daerah incumbent didasarkan oleh iming-iming promosi jabatan. Seperti halnya yang terjadi Kabupaten Boyolali, Badan Pengawas Pemilihan Umum (Bawaslu) menegaskan ketidaknetralan PNS di Boyolali masuk nomor satu di Indonesia. Hal itu diperkuat dengan maraknya laporan PNS terindikasi tidak netral di Pemilihan Kepala Daerah Boyolali yang dilaporkan ke Panwaslu (http://www.solopos.com). Sedangkan di Lombok Utara, banyak dari PNS yang menjadi tim sukses dari calon incumbent (http:// mataramnews.com). Implikasi ketidaknetralan adalah penempatan jabatan karena kepentingan politik yang tidak berdasar kompetensi, namun lebih karena faktor mariage system bukan merit system. Selain itu, semakin terpuruknya citra pemerintah karena pembangunan sistem kerja yang tidak profesional dan memihak serta menyampingkan asas netralitas (Sri Hartini, et.al, 2014:539).

Penulis sepakat dengan pernyataan Eko Prasojo bahwa konsep netralitas masih dirasakan belum sepenuh hati, karena untuk menjaga netralitas PNS dan terhindar dari politik praktis, UU Nomor 5 Tahun 2014 tentang Aparatur Sipil sNegara (UU ASN) hanya melarang untuk menjadi anggota dan pengurus partai politik. Seiring dengan berkembangnya sistem demokrasi, intervensi politik tidak cukup jika "hanya" diukur dari keterlibatan seseorang sebagai anggota atau pengurus partai politik (Eko Prasojo dan Laode Rudita, 2004:24). Pernyataan Eko Prasojo memiliki korelasi erat dengan lemahnya substansi peraturan tentang netralitas. Dalam kaitan ini, UU ASN tidak pernah menyinggung standar dan kriteria dalam penerapan hubungan kewenangan antara jabatan Presiden atau Kepala Daerah pasca Pemilihan Umum dengan jabatan karier di lingkungan Pemerintah. Padahal hubungan keduanya sangat erat sebagai Pejabat Pembina Kepegawaian dengan Pejabat yang berwenang. Artinya, hubungan tersebut bukan hanya mengatur tentang PNS, namun lebih luas ke dalam struktur kelembagaan dan proses penentuan kebijakan PNS.

Fokus pembahasan lebih lanjut dalam tulisan ini adalah terkait dengan dinamika pemaknaan netralitas dan problem penerapannya. Pasal 2 huruf f UU ASN menyebutkan bahwa penyelenggaraan kebijakan dan manajemen ASN didasarkan pada asas netralitas. Dalam penjelasannya disebutkan bahwa "asas netralitas” adalah bahwa setiap Pegawai ASN tidak berpihak dari segala bentuk pengaruh manapun dan tidak memihak kepada kepentingan siapapun. Terlepas dari pasal tersebut, UU ASN menegaskan bahwa PNS yang merupakan bagian dari ASN tetap diberikan hak untuk memilih dalam Pemilihan Umum serta diberikan ruang untuk dipilih menjadi pejabat negara melalui mekanisme politik.

Mencermati pemaknaan yang memiliki standar ganda, tentunya analisis terhadap makna netralitas dimaksudkan untuk memaksimalkan pelaksanaan tugas pemerintahan yang berdaya guna dan berhasil guna serta mencari hakikat dari makna netralitas sebagaimana diatur dalam UU ASN.

\section{PEMBAHASAN}

\section{A. EKSISTENSI DAN ESENSI ASAS NETRALITAS}

Dalam konsep demokrasi, hak dasar dan hak asasi tidak bisa dilepaskan dari prinsip kebebasan. Prinsip kebebasan bersifat universal yang meliputi bidang sosial, ekonomi, budaya 
dan politik yang dituangkan dalam berbagai deklarasi dan perjanjian internasional. Dalam implementasinya, terdapat perbedaan pengakuan antara hak-hak dasar (grondrechten, fundamental right) dengan hak asasi manusia (mensenrechten, rechten van de mens atau human right). Hak-hak dasar berhubungan dengan pengakuan hukum nasional yang melandasi hakhak lain yang diatur dalam berbagai peraturan perundang-undangan, sedangkan hak-hak asasi manusia biasanya memperoleh pengakuan Internasional. Perbedaan tersebut menurut Soewoto (1993:2) dapat diketemukan di dalam kepustakaan hukum tata negara, yaitu biasanya hak-hak dasar dicantumkan dalam konstitusi, sedangkan hak-hak asasi dibicarakan dalam literatur hukum internasional.

Salah satu hak asasi adalah kebebasan mengeluarkan pendapat dan pikiran melalui kebebasan berserikat dan berkumpul. Dalam tataran implementasi, masalah dasar yang timbul dalam hak asasi manusia adalah keberadaan dari pembatasan kebebasan warga negara dalam turut serta berperan aktif dalam pemerintahan (Sri Hartini, et.al, 2008:24). Secara Internasional, jaminan terhadap kebebasan berserikat dan berkumpul ini di atur dalam ketentuan article 20, Declaration of $\mathrm{Hu}$ man Right. Di dalam ketentuan pasal ini dinyatakan sebagai berikut:

"everyone has the right to freedom of peacefull assembly and asociation and no one may be compilled to belong an association.". Analog isi pasal tersebut adalah (1) setiap orang mempunyai hak atas kebebasan berkumpul dan berpendapat; (2) Tiada seorang juapun dapat dipaksa memasuki salah satu perkumpulan."

Kebebasan seperti diuraikan dalam article 20 tersebut bersifat universal. Namun menurut Soewoto (1993:2) bahwa hak asasi ini bersifat universal, yang tidak universal adalah implementasinya dalam produk perundang- undangan. Pengecualian terhadap universalitas hak asasi disampaikan oleh Philipus M. Hadjon (1994:5) bahwa:

Ide negara hukum (rechstaat) cenderung ke arah positivisme hukum, yang membawa konsekuensi bahwa hukum harus dibentuk secara sadar oleh badan pembentuk undang-undang. Selanjutnya dikatakan bahwa pembentukan undang-undang pada dasarnya dimaksudkan untuk membatasi kekuasaan pemerintah secara tegas dan jelas. Pada sisi lain, pembentukan undang-undang dimaksudkan untuk melindungi hak-hak dasar. Di samping itu, usaha pembatasan hak-hak dasar ternyata juga dengan menggunakan instrumen undang-undang. Karena instrumen utama di dalam negara hukum adalah undang-undang.

Persoalan netralitas PNS merupakan salah satu isu hukum yang bersinggungan dengan esensi kebebasan berserikat. Hal ini seperti dinyatakan oleh S.F. Marbun dan M. Mahfud MD (1998:69) bahwa:

Salah satu persoalan besar bangsa ini dalam kehidupan bernegara adalah persoalan netralitas pegawai negeri, karena secara teoritis sulit ditemukan landasan yang dapat memberikan alasan pembenar bagi dimungkinkannya pegawai negeri untuk terlibat dalam kegiatan-kegiatan politik praktis.

Atas persoalan di atas, maka pemerintah membuat pengaturan tentang pembatasan akivitas PNS yang disebut dengan asas netralitas dalam Pasal 2 huruf $f$ UU ASN. Pengaturan terhadap netralitas PNS dimaksudkan untuk memperoleh kepastian, kegunaan dan keadilan hukum guna membatasi kekuasaan terhadap kemungkinan bergeraknya kekuasaan atas nalurinya sendiri, yang pada akhirnya mengarah pada penyalahgunaan kekuasaan (abuse of power). $\mathrm{Hal}$ ini berarti bahwa pembatasan kekuasaan memiliki korelasi yang erat dengan upaya 
membatasi perilaku dari penguasa. Tidak ada satupun peraturan yang keberlakuannya sepanjang zaman dan memenuhi kebutuhan realitas sosial yang terus berubah, sehingga setiap perubahan pada hakikatnya merupakan konsekuansi logis bagi setiap keinginan untuk memenuhi tuntutan zaman (Ellydar Chaidir, 2008:294). Perubahan perilaku, kondisi, dan kepentingan realitas sosial merupakan akses masuk dibuatnya pengaturan untuk membatasi kegiatan subyek hukum. Hal ini selaras dengan yang dinyatakan oleh Hart mengenai 3 (tiga) kaidah perilaku yang meliputi Pertama, Kaidah Pengakuan (Kaidah Rekognisi). Kaidah yang menetapkan kaidah perilaku mana yang di dalam sebuah masyarakat hukum tertentu harus dipatuhi; Kedua, kaidah Perubahan. Kaidah yang menetapkan bagaimana suatu kaidah perilaku dapat diubah; dan Ketiga, Kaidah kewenangan. Kaidah yang menetapkan oleh siapa dan dengan melalui prosedur yang mana kaidah perilaku ditetapkan dan bagaimana suatu kaidah perilaku harus diterapkan jika dalam suatu kejadian tertentu terdapat ketidakjelasan (J.J.H.Bruggink,1999:104).

Mencermati kaidah perilaku di atas, maka didalam hubungan hukum antara negara dengan PNS ditegaskan tentang ketentuan pembatasan perilaku pegawai yang bekerja dalam instansi negeri. Hubungan ini ini disebut dengan hubungan dinas publik. Implikasi hubungan dinas publik adalah PNS harus setia dan taat terhadap peraturan perundangundangan (Tedi Sudrajat, 2011:406). Inti dari hubungan dinas publik adalah kewajiban bagi pegawai yang bersangkutan untuk tunduk pada pengangkatan dalam beberapa macam jabatan tertentu yang berakibat bahwa pegawai yang bersangkutan tidak menolak (menerima tanpa syarat) pengangkatannya dalam satu jabatan yang telah ditentukan oleh pemerintah di mana sebaliknya pemerintah berhak mengangkat seseorang pegawai dalam jabatan tertentu tanpa harus adanya penyesuaian kehendak dari yang bersangkutan. Karena itu, apabila PNS akan melaksanakan hak-hak asasinya secara penuh, pemerintah dapat menyatakan yang bersangkutan bukanlah orang yang diperlukan bantuannya oleh pemerintah. (Philipus M Hadjon, 1994:214).

Makna pemberlakuan hubungan dinas publik adalah timbulnya pembatasan terhadap diri PNS melalui peraturan yang dikenakan kepadanya, termasuk didalamnya adalah hak-hak yang bersifat asasi. Dalam kaitan ini, walaupun hak asasi manusia diakui sebagai hak yang pada dasarnya tak dapat dikurangi, dirampas sedikitpun oleh siapapun, namun demikian hak asasi manusia bukanlah sesuatu yang bisa dinikmati tanpa batas. Terdapat adagium dalam hukum bahwa penikmatan hak seseorang dibatasi yakni oleh penikmatan hak orang lain. Hal ini memiliki makna yang sama dengan pernyataan dari John Stuart Mill bahwa suatu perbuatan (penikmatan hak) tidak menimbulkan kerugian pada orang lain, maka tidak ada legitimasi bagi negara untuk merepresi suatu penikmatan hak (Satya Arinanto, 2003:4). Sebaliknya, jika memang penikmatan hak akan mengganggu orang lain, maka pembatasan terhadapnya dimungkinkan terjadi. Pembatasan tak semata-mata memiliki justifikasi dengan sekedar adanya hukum positif saja. Pembatasan dimaksudkan untuk menjamin pengakuan serta penghormatan yang layak terhadap hak-hak dan kebebasan orang lain.

Penegasan pembatasan aktivitas pemerintah disampaikan oleh B.J Habibie dalam Rapat Paripurna Sidang Umum ke-8 MPR-RI tanggal 14 Oktober 1999 yang menyatakan bahwa bahwa:

Untuk menghilangkan campur tangan pemerintah dalam proses pemilu, pemerintah mengatur tentang netralitas POLRI, TNI serta PNS. Demikian juga dalam hal pelaksanaan dan pengawasan pemilu, pemerintah menyerahkan 
sebagian besar wewenangnya kepada partai politik peserta pemilu, sedangkan pemerintah lebih menempatkan diri sebagai fasilitator.... selain dari itu, dalam rangka menghapuskan KKN dikalangan PNS, maka dedikasi dan profesionalisme pegawai negri sipil perlu ditingkatkan, seiring dengan perbaikan imbalan yang mereka terima. Kita menginginkan birokrasi yang bersih, netral dan profesional. Pengaturan tentang PNS tidak boleh menjadi anggota dan pengurus partai politik dimaksudkan untuk menjaga netralitas tersebut. Dengan demikian, PNS dapat memberikan pelayanan kepada masyarakat secara profesional, optimal, adil dan merata tanpa mempertimbangkan golongan mampun aliran politik yang ada.

\section{Implementasi dari pembahasan di MPR} kemudian merujuk pada pembentukan konsepsi tentang pembatasan peran serta PNS sebagai maksud untuk menciptakan aparat yang bersih dalam upaya menciptakan good governance. Makna good dalam good governance mengandung 2 (dua) pengertian. Pertama, nilai yang menjunjung tinggi keinginan atau kehendak rakyat, dan nilai yang dapat meningkatkan kemampuan rakyat dalam pencapaian tujuan (nasional), kemandirian, pembangunan berkelanjutan dan keadilan sosial. Kedua, aspek fungsional dan pemerintahan yang efektif dan efisien dalam pelaksanaan tugasnya untuk mencapai tujuan tersebut. Sedangkan untuk makna governance, World Bank mendefinisikan sebagai "the way state power is used in managing economic and sosial resources for development and society”. World Bank mensinonimkan governance dengan penyelenggaraan manajemen pembangunan yang solid dan bertanggungjawab, sejalan dengan demokrasi dan pasar yang efisien, penghindaran salah alokasi dana investasi yang langka dan pencegahan korupsi, baik secara politk maupun administratif, menjalankan disiplin anggaran serta penciptaan legal dan political framework. (Soedarmayanti, 2003:7)

Berdasarkan pengertian tersebut, good governance berorientasi pada Pertama, orientasi ideal, negara yang diarahkan pada pencapaian tujuan nasional. Orientasi ini bertitik tolak pada demokratisasi dalam kehidupan bernegara. Adapun orientasi kedua adalah sejauhmana pemerintah mempunyai kompetensi dan sejauhmana struktur serta mekanisme politik serta administratif berfungsi secara efektif dan efisien. Dalam kaitannya dengan netralitas PNS, maka good governance dapat terealisir jika memiliki aparatur pemerintah yang tidak memihak dan profesional. Pandangan ini sesuai dengan kedudukan manusia, seperti ungkapan "not the man but the man behind the gun" (Sri Hartini, 2009:258).

Secara filosofis, orientasi good governance di atas memiliki korelasi yang erat dengan tipe birokrasi ideal yang berbentuk organisasi yang rasional dan efisien meliputi Pertama, individu pejabat secara personal bebas, akan tetapi dibatasi oleh jabatannya manakala ia menjalankan tugas-tugas atau kepentingan individual dalam jabatannya. Pejabat tidak bebas menggunakan jabatannya untuk keperluan dan kepentingan pribadinya termasuk keluarganya; Kedua, jabatan-jabatan itu disusun dalam tingkatan hierarki dari atas ke bawah dan ke samping. Konsekeuensinya ada jabatan atasan dan bawahan, dan ada pula yang menyandang kekuasaan lebih besar dan ada yang lebih kecil; Ketiga, tugas dan fungsi masing-masing jabatan dalam hierarki itu secara spesifik berbeda satu dengan yang lainnya; Keempat, setiap pejabat mempunyai kontrak jabatan yang harus dijalankan. Uraian tugas (job description) masingmasing pejabat merupakan domain yang menjadi wewenang dan tanggung jawab yang harus dijalankan sesuai dengan kontrak; Kelima, setiap pejabat diseleksi atas dasar kualifikasi 
profesionalitasnya, idealnya hal tersebut

dilakukan melalui ujian yang kompetitif; Keenam, setiap pejabat mempunyai gaji termasuk hak untuk menerima pensiun sesuai dengan tingkatan hierarki jabatan yang disandangnya. Setiap pejabat bisa memutuskan untuk keluar dari pekerjaannya dan jabatannya sesuai dengan keinginannya dan kontraknya bisa diakhiri dalam keadaan tertentu; Ketujuh, terdapat struktur pengembangan karier yang jelas dengan promosi berdasarkan senioritas dan merit sesuai dengan pertimbangan yang obyektif; Kedelapan, setiap pejabat sama sekali tidak dibenarkan menjalankan jabatannya dan resources instansinya untuk kepentingan pribadi dan keluarganya; Kesembilan, setiap pejabat berada di bawah pengendalian dan pengawasan suatu sistem yang dijalankan secara disiplin. (Miftah Thoha, 2007:18)

Berdasarkan sembilan tipe ideal birokrasi yang rasional tersebut, maka birokrasi dimaksudkan untuk memisahkan antara manusia dengan jabatan (birokrasi) yang melekat dalam manusia itu sendiri. Dalam hal ini, Weber memberikan pemikiran untuk mencegah kecenderungan yang melekat dalam birokrasi, yaitu akumulasi kekuasaan dari suatu kedudukan dengan maksud untuk menciptakan keseimbangan dalam fungsi birokrasi.

Hal di atas bermakna bahwa pembatasan peran serta PNS dalam proses politik memiliki korelasi yang erat dengan konsepsi birokrasi yang berorientasi pada legitimasi, otoritas dan rasionalitas. Dalam upaya menjaga netralitas PNS dari pengaruh kepentingan politik dan untuk menjamin keutuhan, kekompakan, dan persatuan PNS, serta agar dapat memusatkan segala perhatian, pikiran, dan tenaganya pada tugas yang dibebankan kepadanya, maka setiap kegiatan PNS harus dilandasi pada asas netralitas.

\section{B. REKONSTRUKSI MAKNA ASAS NETRALITAS DALAM UU ASN}

Dalam konteks keilmuan, pencarian makna netralitas akan selalu terkait dengan obyektivitas cara pandang. Dalam kaitan ini, kebenaran objektivitas ilmu hanya dapat dinilai ketika unsur-unsur subjektivitas ilmu tersebut tidak mempengaruhinya atau tidak masuk sebagai salah satu unsur dari bangunan teori-teorinya. Disini jelas bahwa ilmu pengetahuan akan dikatakan objektif apabila ia terlepas dari unsurunsur lain di luar dirinya, termasuk nilai (value free). Begitu ilmu terbebas dari nilai atau unsurunsur lainnya, maka ilmu dalam keadaan posisi netral, karena ia tidak memihak kepada sesuatu apapun kecuali pada dirinya sendiri (independent). Objektif artinya bahwa data dapat tersedia untuk penelaahan keilmuan tanpa ada hubungannya dengan karakteristik individual dari seorang ilmuwan (Jujun S.

Suriasumantri,1999:115). Bebas nilai berarti dikotomi yang tegas antara fakta dan nilai mengharuskan subjek peneliti mengambil jarak dengan semesta dengan bersikap imparsialnetral.

Berdasarkan analogi terhadap netralitas keilmuan, hakikat akan obyektivitas selalu bermuara pada kondisi netral, maka jelas bahwa substansi netral adalah tidak memihak. Sejatinya, kondisi tidak memihak akan terpenuhi jika berada di luar sistem dan tidak memberikan ruang akan intervensi kepentingan. Saat ini, posisi PNS berada dalam sistem yang terkoneksi dengan kepentingan politik. Di dalam sistem ini terdapat hubungan sinergi antara Presiden/Kepala Daerah dan wakilnya dengan PNS dalam lingkungan kerja yang saling berpengaruh. Apalagi hubungan ini menimbulkan implikasi jabatan karier PNS atas dasar kewenangan Presiden dan Kepala Daerah sebagai Pejabat Pembina Kepegawaian. Jelas, kondisi ini akan mengakibatkan ketidaknetralan 
PNS dalam melaksanakan tugas karena sarat kepentingan. Ketika persoalan netralitas PNS ingin diselesaikan, maka pemerintah cukup mencabut hak pilih dalam pemilihan umum dan hak dipilih sebagai pejabat negara sebagai bagian dari pembatasan. Dasarnya adalah hubungan dinas publik dan contract suigeneris.

Konsep netralitas adalah memberikan pembatasan dan kepastian akan peran dari PNS dalam pemerintahan. Implikasi pembatasan adalah penegakan hukum yang beorientasi pada jaminan PNS dalam melaksanakan tugas secara profesional. Konsep pembatasan ini memiliki korelasi dengan konsep Islam sebagaimana disampaikan oleh Ibnu Timiyah bahwa "Semua kewenangan dalam Islam tujuannya hanyalah amar maruf nahi munkar" (Ni'matul Huda, 2010: 47-48). Pada hakikatnya, kewenangan tersimbol dalam tugas pengawasan atas orang-orang yang memiliki kekuasaan - berarti mewujudkan partisipasi politik rakyat dalam segala perkaraperkara umum dan juga dalam hukum. Konsep ini dapat dikorelasikan dengan hakikat dari netralitas yang luarannya adalah pembentukan karakter profesional bagi PNS dalam pelayanan publik.

\section{PENUTUP}

\section{A. SIMPULAN}

Konsep pembatasan didasarkan pada konsepsi negara hukum demokratis yang berorientasi pada penerapan good governance guna menciptakan perubahan kaidah perilaku yang menempatkan hubungan dinas publik dalam hukum kepegawaian. Adapun pembatasan hak politik bagi PNS dapat ditolerir sepanjang untuk menjamin pengakuan serta penghormatan atas hak dan kebebasan orang lain, dan untuk memenuhi tuntutan yang adil sesuai dengan pertimbangan moral, keamanan, dan ketertiban umum dalam suatu masyarakat demokratis. Atas dasar itu, maka pemaknaan terhadap netralitas adalah membatasi kewenangan dari PNS untuk tidak memihak dalam kegiatan politik.

\section{B. SARAN}

Hubungan antara PNS dengan politik praktis merupakan persoalan yang selalu terjadi ketika terdapatnya ambiguitas penafsiran dan meleburnya aspek politik di lingkungan pemerintahan. PNS sering kali dijadikan sebagai gejala sosial yang mempengaruhi lingkungan masyarakat sebagai sosok priyai yang terhormat dan diperhitungkan. Pada posisi tersebut, PNS ditempatkan sebagai media yang strategis dalam mempengaruhi dan merekrut massa yang ditengarai sebagai titik rawan PNS sehingga menjadi tidak netral dan rentan pelanggaran. Atas dasar itu, pemerintah perlu merasionalisasikan pembatasan peran PNS dalam bentuk produk peraturan perundangundangan (secara hierarkis) dan pemerintah harus membuktikan bahwa pembatasan tersebut dilakukan hanya untuk menjamin pembangunan hukum yang demokratis. Standarnya adalah terlepasnya segala bentuk kegiatan politik praktis, termasuk dicabutnya hak pilih dan dipilih sebagai pejabat negara.

\section{DAFTAR PUSTAKA}

Buku

Arinanto, Satya, 2003, Hak Asasi Manusia Dalam Transisi Politik Indonesia, Jakarta, FH-UI

Bruggink, J.J.H., 1999, Refleksi Tentang Hukum (Terjemahan Berhard Arief Sidharta), Bandung, Citra Aditya Bakti

Chaidir, Ellydar, 2008, Sistem Pemerintahan Negara Republik Indonesia Pasca Perubahan Undang-Undang Dasar 1945, Yogyakarta, Total Media

Hartini, Sri, et.al., 2008, Hukum Kepegawaian di Indonesia, Jakarta, Sinar Grafika

Huda, Ni'matul, 2010, Problematika Pembatalan Peraturan Daerah, Yogyakarta, FH UII Press

Marbun, S.F. dan M. Mahfud MD, 1987, Pokok-Pokok Hukum Administrasi Negara, Yogyakarta, Liberty

Soedarmayanti, 2003, Good Governance (Kepemerintahan Yang Baik) Dalam Rangka Otonomi Daerah, Bandung, Mandar Maju

Suriasumantri, Jujun S., 1999, Tentang Hakekat IImu: Sebuah Pengantar Redaksi, dalam IImu Dalam Perspektif,, Jakarta, Yayasan Obor

Thoha, Miftah, 2007, Birokrasi dan Politik di Indonesia, Jakarta, Raja Grafindo Persada

Jurnal, Makalah dan Internet 
Hadjon, Philipus M., 1994, "Ide Negara Hukum dalam Sistem Ketatanegaraan Republik Indonesia", Makalah Simposium tentang Politik, Hak Asasi dan Pembangunan Hukum, Makalah ini disampaikan dalam Rangka Dies Natalis XL/Lustrum Universitas Airlangga 3 November 1994

Hartini, Sri, 2009, Penegakan Hukum Netralitas Pegawai Negeri Sipil, Jurnal Dinamika Hukum FH Universitas Jenderal Soedirman Purwokerto, Vol. 9 No.3

Hartini, Sri, et.al, 2014, Kebijakan Netralitas Politik Pegawai Negeri Sipil dalam Pemilukada (Studi di Jawa Tengah), Padjadjaran Jurnal IImu Hukum, Vol. 3 No.3

Ismail, Muhammad, ("Bawaslu: Ketidaknetralan PNS Boyolali Nomor 1 di Indonesia"), http://www.solopos.com/2015/12/09/ pilkada-boyolali-baw-aslu-ketidaknetralan-pns-boyolali-nomor1-di-indonesia-669108, diunduh pada Selasa, 31 Mei 2016, jam.19.30 WIB.

Mataram News, ("Jelang Pilkada PNS Harus Netral"), http:// mataramnews.com /sorot/item/4701-jelang-pilkada-pns-harusnetral,, diunduh pada Selasa, 31 Mei 2016, jam.18.38 WIB.

Prasojo, Eko dan Laode Rudita, Undang-Undang Aparatur Sipil Negera; Membangun Profesionalisme Aparatur Sipil Negara", Civil Service, Jurnal Kebijakan dan Manajemen PNS, Pusat Pengkajian dan Penelitian Kepegawaian BKN Jakarta, Vol. 8 No.1

Soewoto, 1994, "Hak Asasi Manusia Masalah Konsep, Penjabaran, Pelaksanaan dan Pengawasan di Indonesia", Makalah pada Dies Natalis Brawijaya ke-31 Universitas Brawijaya 1 Januari 1994

Sudrajat, Tedi, 2011, Implikasi Hukum Pembatasan Peran Serta Pegawai Negeri Sipil Dalam Proses Politik di Indonesia, Jurnal Dinamika Hukum FH Universitas Jenderal Soedirman Purwokerto, Vol.11 No. 3 